University of Nebraska - Lincoln

DigitalCommons@University of Nebraska - Lincoln

Agronomy \& Horticulture -- Faculty Publications

Agronomy and Horticulture Department

$1-1960$

\title{
Comparison of Vegetation of Kansas-Nebraska Drift-Loess Hills and Loess Plains
}

J. E. Weaver

University of Nebraska-Lincoln

Follow this and additional works at: https://digitalcommons.unl.edu/agronomyfacpub

Part of the Plant Sciences Commons

Weaver, J. E., "Comparison of Vegetation of Kansas-Nebraska Drift-Loess Hills and Loess Plains" (1960). Agronomy \& Horticulture -- Faculty Publications. 481.

https://digitalcommons.unl.edu/agronomyfacpub/481

This Article is brought to you for free and open access by the Agronomy and Horticulture Department at DigitalCommons@University of Nebraska - Lincoln. It has been accepted for inclusion in Agronomy \& Horticulture -Faculty Publications by an authorized administrator of DigitalCommons@University of Nebraska - Lincoln. 


\section{COMPARISON OF VEGETATION OF KANSAS-NEBRASKA DRIFT-LOESS HILLS AND LOESS PLAINS \\ J. E. Weaver \\ Department of Botany, University of Nebraska, Lincoln}

The western edge of True Prairie gives way very gradually on the Loess Plains south of the Platte River to Mixed Prairie of the Great Plains. North of the Platte a similar transition occurs in the valleys and on the slopes of the Loess Hills. But in northern Kansas the True Prairie of the Kansas-Nebraska Drift-Loess Hills is definitely separated by the Flint Hills Region from its western edge on the Kansas-Nebraska Loess Plains. In this study the vegetation, soils, and other environmental factors of the two areas are described and compared.
Names of grasses are according to Hitchcock and Chase (1950) revised Manual of Grasses of the United States. Other scientific names follow Gleason's (1952) New Britton and Brown Illustrated Flora.

\section{Area of Study}

These studies were made in northeastern Kansas and in the eastern portion of north-central Kansas (Fig. 1). They were mostly in the two tiers of counties adjacent to the Kansas-Nebraska state line but also included the adjoining tier of 


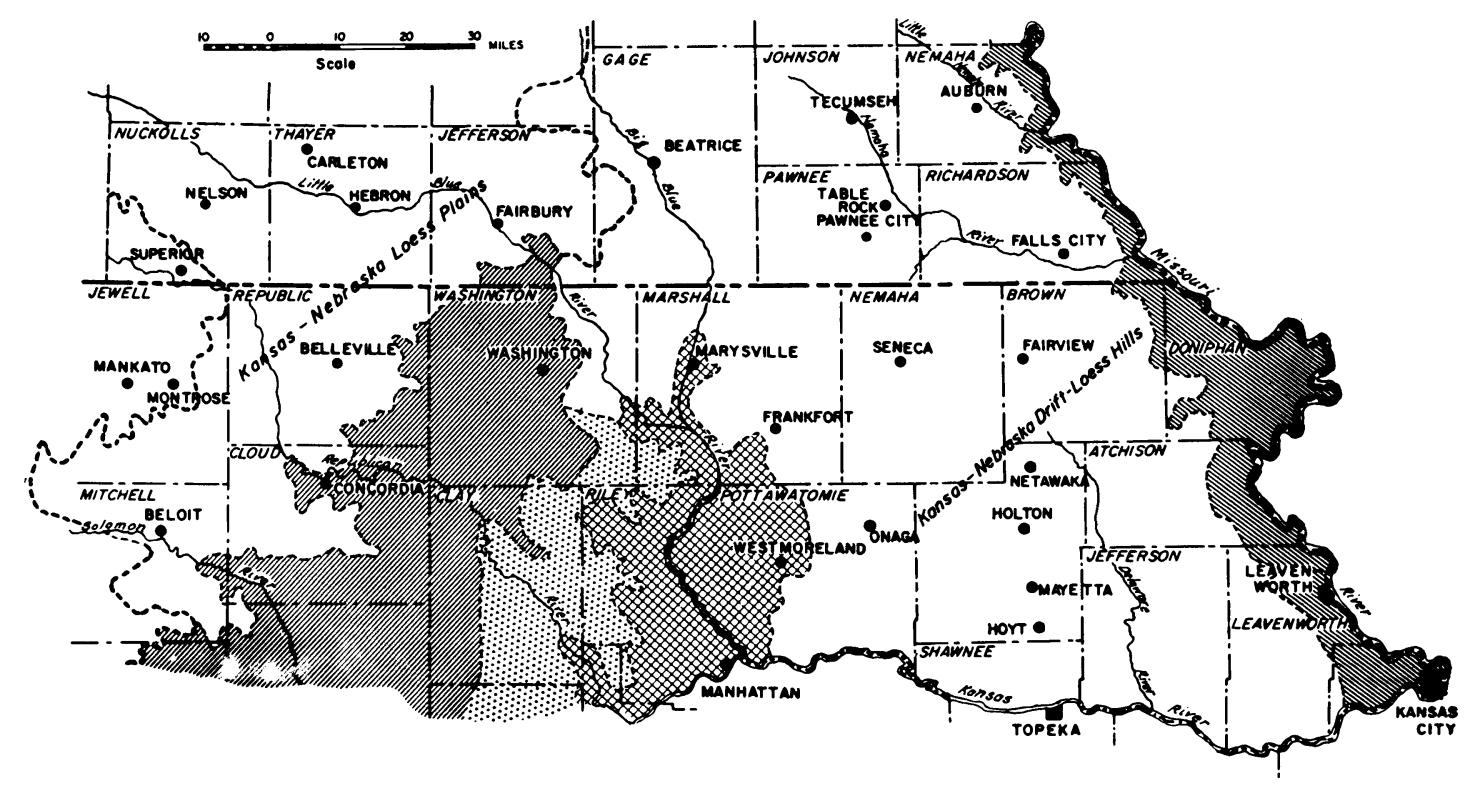

FIG. 1. Map of the Kansas-Nebraska Drift-Loess Hills and Loess Plains. The Flint Hills and other areas separating them, and the Loess Hills Region along the Missouri River are also shown. The heavy broken line separates Kansas (southward) from Nebraska.

counties in southern Nebraska. Most of the work was done in 1929-32 before the great drought of 1933-40, but the results have been confirmed by further examinations in 1952-53 and 1959. The eastern area is the Kansas-Nebraska Drift-Loess Hills, a large territory which lies north of the Kansas River (Fig. 1). The western area is the Kansas-Nebraska Loess Plains, about 100 miles westward. They are separated in part by the Flint Hills (cross-hatch) and partly by the ShaleSandstone Section (parallel lines) of the Central Kansas Rolling Plains Region.

The Flint Hills Region occupies the western half of the eastern third of Kansas. It extends southward from near the Nebraska state line entirely across the state. The general width is about $60 \mathrm{mi}$, but it narrows north of the Kansas River to about $30 \mathrm{mi}$. The region was so called from the underlying cherty or flinty limestone. Here the soils have developed on Pennsylvanian limestone. From the excellent cover of bluestem grasses it is often designated as the Bluestem Hills.

In the Shale-Sandstone Section which lies westward, in northern Kansas, there are extensive areas where sandstone caps the hills and rough broken lands; the eroded lower parts are chiefly clays and shales. In this area the soils have developed on Dakota Sandstone and Permian Shales. Deposits of pale yellow and brownish loess are on the nearly level to gently sloping, narrow divides in the northern third of the area (cf. Fly
1946). The entire area was formerly covered with bluestem prairie. This, however, was not of the same high-yielding capacity as that of the Bluestem Hills. In the small, dotted part between the preceding areas the soil developed on loess overlying Permian Shales.

Thus, in Kansas, the Kansas-Nebraska DriftLoess Hills are distinctly separated from the Kansas-Nebraska Loess Plains. Northward, however, the Drift-Loess Hills Region, which has been glaciated and also deeply covered with loess, merges gradually into the non-glaciated Loess Plains. True prairie as distinguished from the drier Mixed Prairie just westward, but not shown on the map, occupied the whole of the mapped area (Fig. 1). The Loess Plains section occurs throughout in the Chernozem rather than in the Brunizem (Prairie) Soil Zone.

The northern boundary of Kansas is $40^{\circ} \mathrm{N}$ latitude. The parallel of $39^{\circ}$ is only a few miles south of Topeka. The meridian of $96^{\circ}$ west longitude is slightly east of Seneca, and that of $98^{\circ}$ is a few miles east of Superior and Montrose (Fig. 1). Altitude in the Drift-Loess Hills ranges from approximately 1,300 ft (Frankfort, Seneca and Onaga ) to about $1,000 \mathrm{ft}$ near Topeka. At Table Rock it is $1,100 \mathrm{ft}$. The Loess Plains are somewhat higher, 1,600 to $1,500 \mathrm{ft}$.

\section{Climate}

The climate is characterized by moderately long, cold winters and a growing season of about 165- 
180 days, late April to early October, without killing frost. Normal summer temperatures are about $75^{\circ} \mathrm{F}$, but the maximum day temperatures may reach $100^{\circ} \mathrm{F}$ or more. Mean annual precipitation at the Loess Plains stations, before the great drought in 1933-1940, was 25 in. at Montrose and 27 in. at Hebron. Over the Drift-Loess Hills it varied mostly from 28 to 33 in., but reached a maximum of 37 in. in the extreme southeast. Westward from the Missouri River along the Kansas-Nebraska border rainfall decreases at an average rate of $1 \mathrm{in}$. per $15 \mathrm{mi}$. to Superior, Nebraska. Seasonal distribution is very favorable to the growth of grasses; 75 to $79 \%$ usually occurs between April 1 and September 30 . Winds, although often high, are less frequent and of lower velocities in the eastern prairies than on the Loess Plains. Humidity is often 10-15\% higher east than west of the Flint Hills, and evaporation is much greater westward. According to Thornthwaite's (1931) P-E index, precipitation effectiveness is much greater in the Drift-Loess Hills. Here it ranges from 56 to 64 , but in the western area from 44 to 48 .

\section{The Kansas-Nebraska}

\section{Drift-Loess Hills}

Southeastern Nebraska and a large area in Kansas north of the Kansas River and east of the Flint Hills is known as the Drift-Loess Hills (Fig. 1). The soils, previously developed over bedrock of limestone, flint rock, sandstone and limey and clayey shales, were covered by debris brought down by the great ice sheets, the Kansan glacier. In the southern part, however, the till sheet was relatively thin. Before the glacial drift was capped by loess, erosion had removed and resorted considerable amounts of this material. The mantle of Peorian Loess and later deposits is thickest (100 $\mathrm{ft}$ in places) along the bluffs of the Missouri River (Frye and Leonard 1951). It decreases in depth westward, for example, to about $6 \mathrm{ft}, 13 \mathrm{mi}$. southwestward in Brown County (Hanna and Bidwell 1955). These investigators state, "There seems to be fairly general agreement that in the Mississippi Valley, including the Missouri River, loess was deposited by wind and that its source was the flood plains of the Pleistocene rivers" (Leonard and Frye 1954). The Loess Hills Region is a strip 6 to $15 \mathrm{mi}$. wide along the Missouri River with a thick covering of loess derived from the Missouri flood plain. Westward the Platte and other Pleistocene Rivers may have furnished the thinner layer of wind-blown loess.

The topography, soils, and vegetation of the eastern and western areas will be considered separately.

\section{Topography and Soils}

The Kansas-Nebraska Drift-Loess Hills Region generally "has narrow, gently rolling divides, with long, moderate to moderately steep slopes broken by rough, stony land, and bedrock outcrops just above the smooth broad valleys. The southern part is much more rolling and is hilly to rough and broken in places" (Fly 1946). Drainage is southward except in Richardson County, Nebraska, in the northern part of Nemaha and Brown counties, Kansas, and along the eastern edge where the streams flow to the Missouri River. Winds have deposited fine silts and clays over much of the region, especially the northern half.

Chief soil series are Grundy, Crete, Pawnee, Burchard and Shelby. The first two are silty clay loam soils derived from loessial parent materials and occur on the nearly level divides. Pawnee, Burchard and Shelby soils, derived from glacial till, occur mostly on undulating to rolling land. In general, the bedrock usually lies 5 to $25 \mathrm{ft}$ or more below the soil surface. All the soils are very dark-grayish or dark-grayish brown. Permeability varies from moderate (Burchard) to very slow in Crete and Pawnee soils. Both soil and subsoil have high water-holding capacity ( $c f$. Bidwell 1956). There is no distinct layer of lime accumulation although the lime is not completely leached from the subsoils. Under grass they are nearly neutral to somewhat acid in reaction. Productivity is moderately high. Dominant crops are corn, small grains, alfalfa and sweet clover, and grasses. "Next to the Loess Hills region, this is the state's most productive area" (Fly 1946).

\section{The Prairie Grasses}

It has been ascertained after many years of study that the vegetation of True Prairie on uplands consists of three major types or communities. Dominant grasses, after which the communities are named, are little bluestem $(A n$ dropogon scoparius), needlegrass (Stipa spartea) and prairie dropseed (Sporobolus heterolepis). Several other mid grasses of importance occur in variable abundance in each of these types, but none forms a community of its own.

Prairie of the more moist and wet lowlands is also composed of three communities, each dominated by tall grasses. The most extensive is that of big bluestem (Andropogon gerardi). A second community occurs in soils usually of higher water content than that of the preceding. It is com- 
posed mostly of switchgrass (Panicum virgatum) but also of Canada wild-rye (Elymus canadensis). Prairie cordgrass (Spartina pectinata) forms a third tall-grass community. It originally occurred in nearly pure stands over hundreds of square miles of first bottom lands along the Missouri and other great rivers and their tributaries.

Mid grasses of uplands can not compete successfully with tall grasses on lowlands because of the dense shade produced by them. Conversely, upland soils are usually not sufficiently moist to promote good development of tall grasses, especially in competition with mid grasses. Of course there is much intermixing of some tall grasses on lower hillsides, or even on level, poorly drained hilltops. Conversely, mid grasses are often scattered sparingly over lowlands. General descriptions of the prairie communities, including their composition and structure, have been given by Weaver and Fitzpatrick (1934). A more succinct statement may be found in North American Prairie (Weaver 1954).

In the area of this study little and big bluestem were by far the most abundant grasses. Prairie dropseed and needlegrass occurred only locally. The prairie cordgrass and switchgrass-wildrye communities were of common occurrence, but they will be considered only incidentally, since those along the Missouri River and its tributaries in True Prairie have recently been fully described (Weaver 1960).

The characteristic habits of growth, the relations of the roots to tops, and certain other characteristics of the several community dominants are shown in Figures 2 and 3 . The tall grasses of the lowland types are sod formers as a result of their rhizome development. The great foliage height of big bluestem, about $3.5 \mathrm{ft}$, is exceeded by that of switchgrass, and both are surpassed by prairie cordgrass. Flower stalks of switchgrass may attain heights of 6-7 ft and those of big bluestem and prairie cordgrass 6-10 ft. In the figures only the amount of tops that occurred in a strip of soil 1 in. in width is shown. Likewise the average number of roots is from an inch-wide column of soil. These data were ascertained for each foot in depth from perpendicular walls of trenches and from monoliths taken from many different soils. Relative width of the main roots of the several grasses is also shown. Only enough detail has been added to indicate the branching habits.

In upland, True Prairie grasses the bunch habit of growth prevails. The average spacing of bunches, about 1-1.5 ft apart, is shown. The largest roots have only about one-third the di-

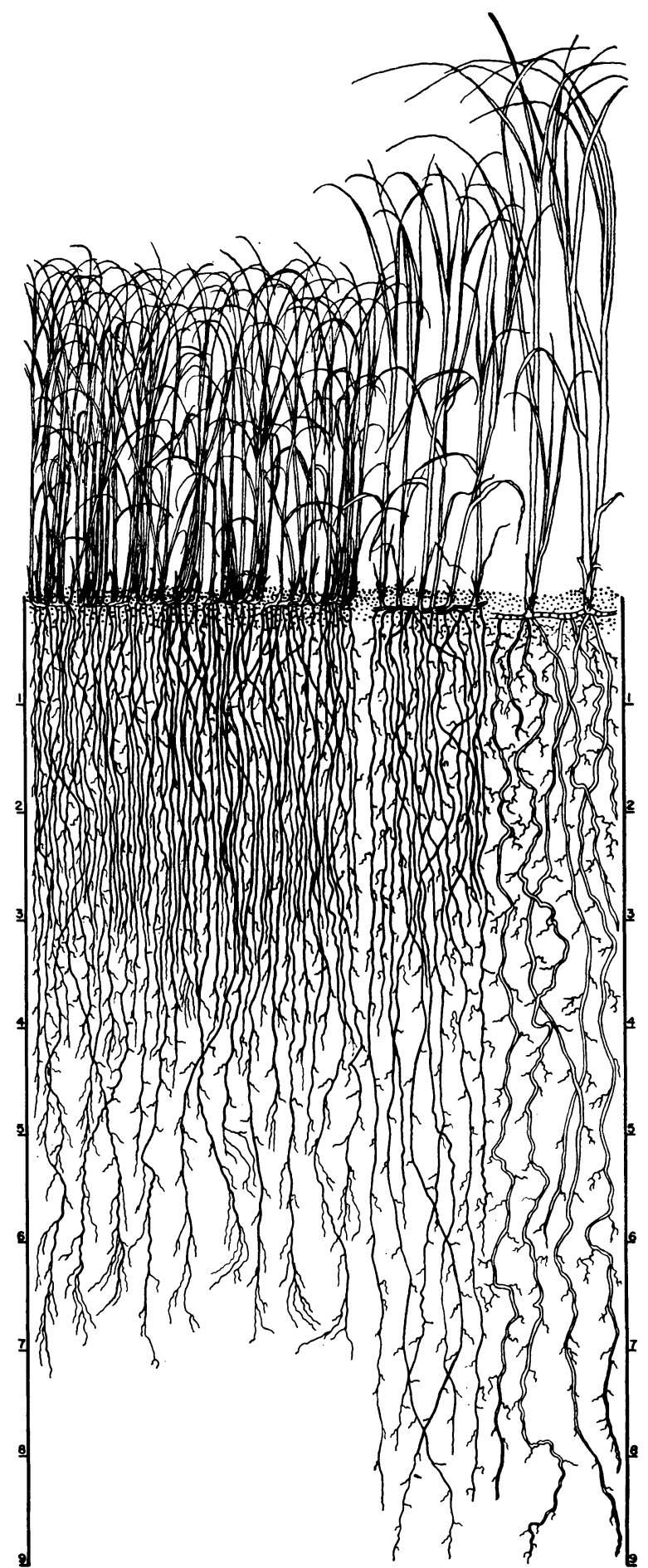

FIg. 2. Characteristic development of tops and roots of big bluestem (Andropogon gerardi) (left), switchgrass (Panicum virgatum), and prairie cordgrass (Spartina pectinata) (right). When flower stalks are fully developed and flowering occurs, heights of 6 to 10 feet are attained.

ameter of those of big bluestem. Note that the soil beneath the crown and on all sides of it to a 


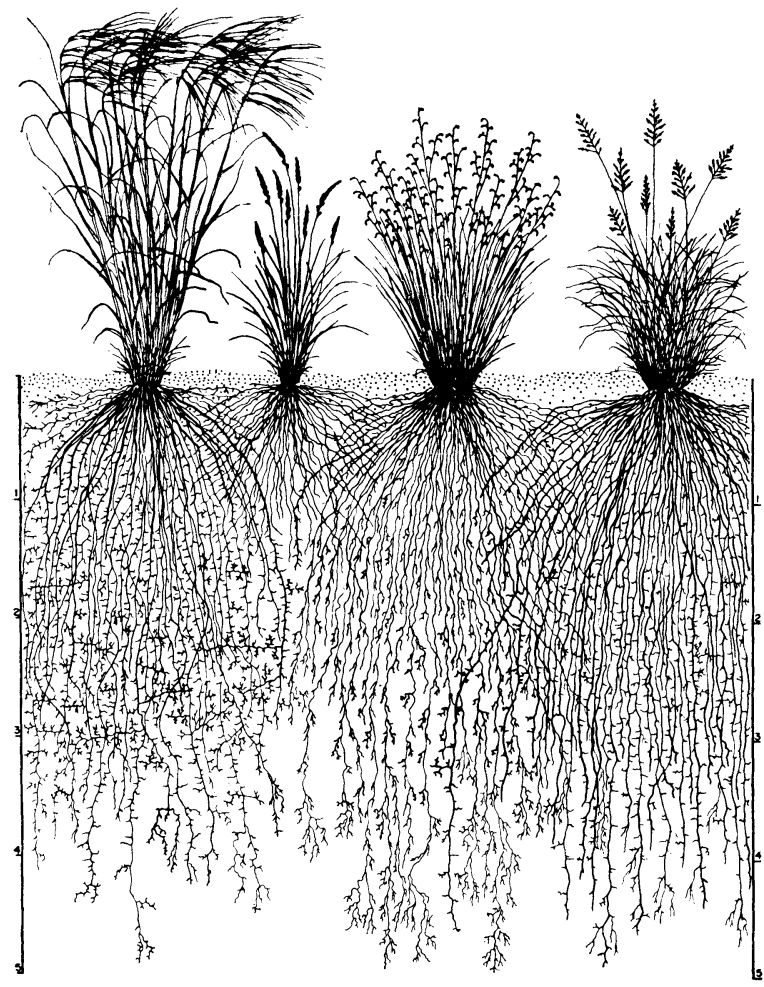

Fili. 3. Characteristic development of tops and roots of four bunch grasses as they occur in the several upland communities. From left to right they are needlegrass (Stipa spartea), Junegrass (Kocleria cristata), little bluestem (Andropogon scoparius) and prairie dropseed (Sporololus hetcrolcpis). Note that the tops are only al:out half as high as the roots are deep.

distance of 12-16 in. is threaded with dense mats of roots to a depth of 4-5 ft. A thorough study of the underground development in natural grassland communities was summarized by the writer in 1958, from which the following paragraphs are taken.

The sod-forming tall grasses of lowland communities of true prairie are of the greatest height $(5-10 \mathrm{ft})$, have the greatest leaf surface, and produce the largest amount of forage. Their roots are coarsest, least well branched, but deepest. They are about as deep (7-10 ft) as the stems are tall. Roots do not spread widely just below the soil surface. All of the dominants, except Elymus canadensis, are warm-season grasses that grow all summer and flower late.

Upland mid grasses nearly all grow in bunches. They are of intermediate height $(2-3.5 \mathrm{ft})$, leaf surface, and amount of forage production. Roots are moderately fine, well branched, and moderately deep. They are about twice as deep (4-5.5 ft) as the stems are tall. They are fairly well spread and moderately dense just beneath the soil surface. Grasses from lnwland, when growing in upland, are reduced in size and weight. The roots are somewhat finer and more branched but penetrate less deeply. There are several coolseason grasses on uplands which flower early but most are warm-season species, flowering late after a long season for growth.

\section{Prairies Near Topeka}

Two large prairies, totaling more than 300 acres, were examined. One was about $11 \mathrm{mi}$. north of Topeka and the other about $2 \mathrm{mi}$. north of Hoyt (Fig. 1). The hills varied from 50 to more than $100 \mathrm{ft}$ in height above the valleys. In both prairies little bluestem dominated on the hilltops and upper and mid slopes, but on lower slopes as well as on gently sloping land in the valley big bluestem was the chief grass.

On the hilltops where the drift soil overlying the limestone was shallow the cover of vegetation was variable. Little bluestem and prairie dropseed in various mixtures often dominated locally. More usually little bluestem, in the bunch form, prevailed and often alone composed $80-90 \%$ of the vegetation. Height of foliage was only 9-11 in. in midsummer and in places the foliage cover did not exceed $50 \%$. Big bluestem was present in small tufts or bunches only to the extent of about $5 \%$.

Over the hilltops and ridges in general, little bluestem was the most abundant grass, usually about $70 \%$ in amount and in midsummer 18-24 in. high. In places with more moist soil big bluestem increased to $15-40 \%$ locally, but over the hilltops as a whole it averaged about $5 \%$. Here it occurred mostly in the bunch form. Switchgrass grew as scattered tufts more or less throughout but rarely, except very locally, exceeded $5 \%$ in abundance. Indian grass (Sorghastrum nutans) was even less abundant. As a result of marked variations in soil depth and water content, vegetation appeared very uneven in both height-growth and density of stand. Eastern gamagrass (Tripsacum dactyloides) was found where seepage occurred; Canada wild-rye was sparsely represented.

The hillsides were clothed with a mixture of little and big bluestem. The first was dominant on higher ground, but big bluestem increased to $50 \%$ or more on the lower slopes and the level base. Here it prevailed in the sod type, sometimes forming as much as $60-80 \%$ of the vegetation. This distribution was readily apparent but was verified by a large number of square-meter quadrats (Table I).

The percentages are not based upon foliage cover (the area occupied by the spreading tops 
TABle I. Percentage composition of vegetation in square meter quadrats from upper slope to the base of a long, rather gentle south slope near Topeka; July 1930

\begin{tabular}{|c|c|c|c|c|c|c|c|c|c|c|c|c|c|c|c|c|c|c|c|c|}
\hline \multirow{2}{*}{ 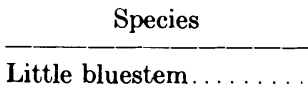 } & \multicolumn{5}{|c|}{ Upper slope } & \multicolumn{5}{|c|}{ Mid slope } & \multicolumn{5}{|c|}{ Lower slope } & \multicolumn{5}{|c|}{ Level base } \\
\hline & 68 & 65 & 40 & 81 & 69 & 70 & 66 & 52 & 75 & 47 & 12 & 15 & 18 & 15 & 8 & 13 & 16 & 8 & 5 & 12 \\
\hline Big bluestem......... & 7 & 10 & 9 & 10 & 8 & 20 & 16 & 30 & 20 & 13 & 67 & 63 & 60 & 65 & 71 & 76 & 80 & 84 & 89 & 77 \\
\hline Prairie dropseed. & 14 & 15 & 50 & - & - & 9 & 5 & 6 & - & - & - & - & - & - & 2 & - & - & - & - & - \\
\hline Switchgrass.... . & - & - & - & 2 & 8 & - & - & 10 & 4 & 5 & 2 & - & 5 & 6 & - & 8 & 2 & - & - & 11 \\
\hline Indian grass. . & 1 & - & - & 2 & - & 1 & 6 & - & 1 & 3 & - & 8 & 4 & 3 & 6 & 2 & 1 & 5 & - & 0 \\
\hline Foliage cover $\%$ & 55 & 50 & 65 & 50 & 60 & 70 & 65 & 75 & 80 & 80 & 100 & 90 & 100 & 95 & 100 & 95 & 100 & 100 & 100 & 100 \\
\hline Basal area $\% \ldots$ & 15 & 14 & 10 & 13 & 15 & 14 & 11 & 12 & 18 & 10 & 13 & 13 & 13 & 12 & 14 & 13 & 15 & 16 & 13 & 15 \\
\hline
\end{tabular}

of the plants in the several layers of vegetation above the soil surface). This varies with the progress of the season and from dry to wet years. In July and later it was usually $75-100 \%$. The basal or ground cover is the actual area occupied by the stems, mats, or tufts of plants about an inch above the soil surface. It is fairly stable and varies but little from month to month or year to year. The part of the total basal cover (considered as unity) composed by each species is that shown in Table I. The remaining basal cover was that of other vegetation. It should be noted that the two bluestems usually composed fully $80 \%$ of the vegetation. The nature of these warmseason, perennial, dominant grasses has previously been fully described (Weaver and Fitzpatrick 1932).

Where seepage occurred on hillsides both eastern gamagrass and switchgrass were common. Even on lowlands little bluestem was usually second in abundance. In places switchgrass had an abundance of $10 \%$ but Indian grass seldom exceeded $5 \%$. In the wet soil of valley floors big bluestem was replaced by prairie cordgrass and eastern gamagrass. In both prairies side-oats grama (Bouteloua curtipendula) was intermixed throughout the bluestems but in very small amounts. Junegrass (Koeleria cristata) was common, except among the tall grasses on low ground, and often abundant where other vegetation was not dense. Needlegrass was rarely found. The wide range of switchgrass over much of the area was quite different from the restricted one in prairies on the deep loess soil of southwestern Iowa (Weaver 1958b).

\section{Onaga Prairies}

Excellent, annually mowed prairies are plentiful near Onaga and southward to the Kansas River. From $75-90 \%$ of the land is used for grazing because of the rock-filled soil, in places glacial boulders, elsewhere limestone or sandstone.

Along an intermittent stream in the valley at the foot of the hills, dense stands of prairie cord- grass were found. This coarse grass attained a foliage height of $6.5 \mathrm{ft}$. It alternated with patches of eastern gamagrass of similar stature and even coarser foliage. In places the two intermingled. A characteristic understory, especially to cordgrass, was composed of scarlet strawberry (Fragaria virginiana), yellow sheep sorrel $(O x$ alis stricta), stiff marsh bedstraw (Galium tinctorium), American germander (Teucrium canadense) and fringed loosestrife (Steironema ciliatum). Tall forbs, such as water hemlock (Cicuta maculata), saw-tooth sunflower (Helianthus grosseserratus), entire-leaved rosinweed (Silphium integrifolium) and tall goldenrod (Solidago altissima) also were common but not abundant. Indigo bush (Amorpha fruticosa), rough-leaved dogwood (Cornus drummondi) and coralberry (Symphoricarpos orbiculatus) occurred in ravines. In a few places little bluestem extended downward from the upland and gave way abruptly to prairie cordgrass or eastern gamagrass. But usually there was a wide transitional belt on lower slopes where big bluestem was dominant and little bluestem from the mid slopes intermingled with it in moderate amounts.

On lower slopes there was a wonderfully developed stand of big bluestem. Its midsummer foliage height was 28-34 in. Intermixed in small amounts were tall plants of side-oats grama and larger proportions of Canada wild-rye and switchgrass. Indian grass, with a height similar to that of big bluestem, composed in places as much as $5-8 \%$ of the cover. Only small amounts of Kentucky bluegrass (Poa pratensis) were found. The total foliage cover was $90-100 \%$.

On the mid slopes vegetation varied from a dense cover of grasses, mostly little bluestem of the sod-mat type, to places where the grasses were intermixed with a great abundance of forbs. Nearly always little bluestem was $18-22$ in. tall by midsummer, and it frequently grew in nearly pure stands. It formed the bulk of the vegetation over the mid and upper slopes; the foliage cover was $80-90 \%$. Big bluestem produced good stands in 
places but it was mostly mixed with little bluestem, in amounts of only $1-15 \%$. It exceeded the dominant in height by about 6 in. Halfway down some north-facing slopes the two bluestems were of about equal abundance, but little bluestem often composed a considerable part of the cover on drier, lower slopes.

On hill crests where the rock sometimes outcropped, the cover of grass was thinner, but forbs were of more than usual abundance. This resulted in an uneven, ragged appearance of the prairie. But often there was as much big bluestem, switchgrass, and side-oats grama here as in apparently deeper soil on the hilltops. Even on mid slopes where rock outcropped there was a similar open cover and some bare soil occurred.

Other grasses generally varied greatly in amount over the prairies, but none attained the rank of the bluestems. Indian grass usually formed $1-5 \%$ of the cover but it had a very irregular distribution, and on some ridges it increased to $15-25 \%$. Kentucky bluegrass varied in amount from 0 to $3 \%$. Prairie dropseed occurred sparingly in a few places, some on upper slopes, some on low ground. Scattered plants of Canada wildrye and switchgrass were found throughout. Like eastern gamagrass they were most abundant about hillside seeps. Side-oats grama ranged throughout but was of most frequent occurrence, 1-5\%, on upland. Needlegrass was infrequent; scattered plants grew on the driest ridges or in washes on lowland. Junegrass was often absent; it rarely exceeded 5\% anywhere. Low-growing panic grasses such as Panicum scribnerianum and $P$. wilcoxianum, and also penn sedge (Carex pennsylvanica) were never very abundant.

In many ungrazed prairies both switchgrass and Indian grass were often scattered throughout. In midsummer when the little bluestem foliage was 20 in. high on upland, Indian grass usually was 8 in. and switchgrass often 16 in. taller, although neither was as tall here as on lowland. Each was represented by a few widely scattered stems, by bunches, or by small patches of a continuous sod. Since the leaves are more erect than those of the bluestem, this results in an uneven or ragged appearance, which is quite different from the more uniform one in more northerly prairies.

These every extensive bluestem prairies were from June to October a land of waving grasses bedecked by an abundance of varicolored flowers above, within and beneath the foliage of the grasses. The forb population will be considered separately following the distribution of the grasses in other samples of prairie.

\section{Grassland Near Mayetta}

A prairie one sq. mi. in area lies about $20 \mathrm{mi}$. north of Topeka and $25 \mathrm{mi}$. southeast of Onaga. It differed from the preceding ones but little in the hilly topography but was quite different in composition of the vegetation. This resulted from annual burning over a long period of years. It was largely a little bluestem prairie, in which the foliage cover was $80-95 \%$, the dominant often developing the sod-mat type rather than occurring in large, well spaced bunches. Even on the upper slopes and hilltops little bluestem had a midsummer stature of $12-14$ in. It was usually accompanied by a marked development of switchgrass, which was far more abundant in this burned prairie than elsewhere. Switchgrass extended from its usual place in ravines and foot-slopes over all the hillsides and was also common on flat hilltops, thus assuming a distribution similar to that of big bluestem. Switchgrass was so widely scattered that it appeared in most of a series of quadrats, and to a considerable degree it replaced big bluestem.

The deep soil and its good water content were revealed by the presence of tall grasses, including Indian grass, on uplands where their foliage level was often 36 in. high. Big bluestem was dominant only on the lower slopes and in ravines, but it was present nearly everywhere, although not in its usual abundance. Over extensive areas switchgrass, 24-30 in. tall in midsummer, composed $50-80 \%$ of the vegetation. It did not occur in large bunches but had developed an open growth of sod similar to that found on low ground. The forage yield was 1.5 to 2 tons per acre. Eastern gamagrass grew in scattered bunches from lowland to the head of draws, and also occurred in wet depressions on hilltops.

Prairie dropseed was found in several local areas where very large bunches, sometimes $18 \mathrm{in}$. in diameter, were elevated a few inches above the general soil surface and filled with leafy shoots 15 in. high. Isolated tufts occurred elsewhere. There was almost no Junegrass or needlegrass. The almost complete absence of Kentucky bluegrass may be attributed to burning. Forbs were less abundant both in species and numbers than in the prairies previously described. Other burned prairies showed similar deviations in composition from those unmodified by annual burning.

\section{Seneca Prairies}

This large prairie 10-12 mi. southwest of Seneca occurred in several rather distinct sites. These were low, nearly level hilltops, ridges and crests of high hills, upper slopes, and mid slopes grading 
into nearly level lowland and then into swales. The soil seemed uniformly deeper than in the preceding prairies although a few glacial boulders occurred. Only about a third of the area could be classified as typical upland. Except on the ridges, portions of the hilltops, and on the steepest slopes, big bluestem was dominant. In the swales it was intermixed with moderate amounts of switchgrass and Canada wild-rye, and in the wetter places with prairie cordgrass. Thus, it dominated over two-thirds of this prairie area.

On the nearly level hilltops little bluestem and big bluestem with $5 \%$ or more Indian grass were intermixed. Bunches of little bluestem with occasional plants or small patches of prairie dropseed composed about two-thirds of the cover. Where increased runoff occurred, big bluestem decreased in amount and only on some of the low, flat hilltops did it rather constantly exceed little bluestem in abundance.

On hill crests or ridges little bluestem, supplemented by $10-20 \%$ of prairie dropseed, held possession with large, well developed bunches. Here this dominant was about 15 in. tall. The $5-10 \%$ intermixed big bluestem exceeded this midsummer height by 6 in. Low-growing Scribner's and Wilcox' panic grasses were common in the understory.

The little bluestem type on south and southwest slopes did not extend so far downward as in the preceding prairies and the greater abundance of big bluestem became apparent higher up the hillsides. Indeed, on north slopes of low hills it extended almost to the hilltops and little bluestem was reduced to $35 \%$ or less. Foliage of big bluestem and Indian grass in midsummer reached a height of 20-24 in. on upland but 36 in. on low ground.

Others grasses were of little importance. Blue grass varied in amount from 1 to $10 \%$. Side-oats grama and Junegrass were sparse, and needlegrass was almost rare. Canada wild-rye occurred sparingly except in ravines. Several small clumps of coralberry occurred, smooth sumac (Rhus glabra) and roughleaf dogwood grew sparingly in ravines, and a small thicket of wild plum (Prunus americana) was observed. There were a large number of forbs but only a few formed definite societies; most were of no great abundance or infrequent.

This prairie was more mesic than those near Topeka and Onaga, probably due to a deeper soil resulting from thicker deposits of glacial till and loess.

\section{Netawaka and Fairview}

The prairies at Netawaka and northward were increasingly nearer the Missouri River and apparently profited greatly from the deeper layer of loess. Over the low hills and on the higher ones as well, little bluestem was spread like a green carpet. The sod-mat type prevailed everywhere except when it alternated with local areas of prairie dropseed on upland. The density of stand and good height growth as well as an abundance of forbs reflected a productive, well watered soil. On more moist lower slopes little bluestem increased in height but shared its dominance with or was replaced by big bluestem, and to a less extent by Canada wild-rye, switchgrass and Indian grass. Here the general foliage level in midsummer was $2-3 \mathrm{ft}$; the vegetation was more dense and the yield greatly increased. The bordering ravines were occupied by eastern gamagrass, a nut rush (Scleria triglomerata), or prairie cordgrass. Data from numerous quadrats in this prairie are given in Table II.

TABle II. Percentage composition of vegetation as determined by square meter quadrats near Netawaka, Kansas

\begin{tabular}{|c|c|c|c|}
\hline Speries & $\begin{array}{l}\text { Upper south } \\
\text { slope }\end{array}$ & $\begin{array}{l}\text { Upper north } \\
\text { slope }\end{array}$ & Lower slopes \\
\hline Little bluestem. & $9291 \quad 70 \quad 74$ & $\begin{array}{lllll}65 & 63 & 42 & 71\end{array}$ & $45 \ldots$ \\
\hline Big bluestem... & $\begin{array}{llll}5 & 2 & 23 & 12\end{array}$ & $\begin{array}{llll}10 & 5 & 50 & 10\end{array}$ & $\begin{array}{llllll}45 & 23 & 39 & 88 & 89 & 82\end{array}$ \\
\hline Switchgrass.. & -115 & $-30--$ & $-7560-8$ \\
\hline Indian grass. .... & $-11-$ & $-\ldots 3$ & $3 \ldots-\cdots$ \\
\hline Foliage cover $\%$ & $\begin{array}{llll}65 & 75 & 85 & 80\end{array}$ & $\begin{array}{llll}80 & 90 & 85 & 90\end{array}$ & $\begin{array}{llllll}100 & 95 & 95 & 100 & 100 & 100\end{array}$ \\
\hline Basal area $\%$. . & $\begin{array}{lllll}12 & 15 & 11 & 14\end{array}$ & $\begin{array}{llll}13 & 17 & 13 & 14\end{array}$ & $\begin{array}{llllll}17 & 15 & 15 & 19 & 16\end{array}$ \\
\hline
\end{tabular}

Other grasses of $1-5 \%$ in amount occurred in a few of the quadrats. These were needlegrass, Junegrass, Kentucky bluegrass and low-growing panic grasses. In one quadrat on a ridge prairie dropseed composed $97 \%$ of the vegetation, and in a well-watered ravine other quadrats had 97 and $98 \%$ of prairie cordgrass and eastern gamagrass, respectively.

Very similar vegetation prevailed at Fairview and northward. That on the loess hills about Falls City and still farther northward at Auburn and Nebraska City, all just east of the isohyet of 32 in. rainfall, were even better developed. Thornber gave an excellent account of one of these large prairies in 1901, and all were carefully examined by Weaver and Fitzpatrick (1934). In most respects they were identical with those eastward in Bedford, Iowa, and closely similar and only slightly less mesic than those at Corning, Creston, and Guthrie Center in southwestern Iowa (Weaver 1958b). It should be pointed out that 
the loess deposits east of the Missouri River flood plain are deeper than those in Nebraska, probably because of the prevailing westerly winds. Broad, level hilltops in western Iowa still maintain a deep covering of loess where tall grasses thrive and are thus similar to those found on certain hilltops in northeastern Kansas and southeastern Nebraska.

\section{Summary of Grasses}

Little bluestem was the most abundant species. It was nearly always the chief dominant on ridges and upper and mid slopes. It occurred mostly as bunches in the southern part (Topeka, Hoyt, Onaga) but often in the sod-mat form northward. It was also usually dominant on flat hilltops where it composed about two-thirds of the vegetation. Here big bluestem was sometimes locally dominant; but generally over the area little bluestem composed 70 to $80 \%$ of the vegetation. Big bluestem was dominant over low, level land and lower slopes and in places (northward) even over mid slopes. Southward little bluestem was sometimes equally intermixed with it on mid and lower slopes; northward big bluestem often extended farther upland even to the crest on north-facing hillsides. It alone frequently composed $85 \%$ of the grasses in its type.

Prairie dropseed was found in most prairies, usually in nearly pure patches on upper slopes and riclges, sometimes in amounts of $10-20 \%$. Scattered plants of needlegrass were found on the clriest ridges or in lowland washes. Jumegrass and Kentucky bluegrass were often present but nearly always in small amounts. Side-oats grama was most abundant ( 1 to $3 \%$ ) in the little bluestem type, but it also occurred with the tall grasses. The low-growing Panicum wilcoxianum and $P$. scribnerianum, Carex pennsylvanicum and a few other sedges were usually present but not abundant in the understory.

Switchgrass ranged widely from pure stands in lowlands and ravines to bunches or sodded patches on hillsides. Where annual burning was practiced, it partly replaced big bluestem. Canada wild-rye was not at all abundant. Indian grass was widely distributed and intermixed with big bluestem in amounts ranging from 1 to 10 or more per cent. It profited as a result of disturbance by fire. On nearly level hilltops, with greatly decreased runoff and occasional depressions, all of the preceding mid and tall grasses were more or less intermixed. The two bluestems, with considerable amounts of switchgrass and Indian grass, were the most abundant. Prairie cordgrass thrived on wet land, as did also the tall, coarse eastern gamagrass. The latter also grew on hill- sides or flat hilltops where seepage or depressions resulted in a sufficient water supply. A few other prairie grasses, such as Agrostis hiemalis and Eragrostis spectabilis, added little to the cover. Juncus tenuis and Carex festucacea were also present mostly in small amounts.

\section{Prairie Forbs}

Forbs are always present and often abundant in prairies. In places they are more conspicuous, although nearly always of less importance than the grasses. After five years of study in an area of 60,000 sq. mi. in prairie of six states, it was ascertained that 75 species of upland and 67 species of lowland forbs occurred in at least $10 \%$ of the 135 large prairies examined. In addition more than 200 other species were listed (Weaver and Fitzpatrick 1934).

In the present study the relative abundance and importance of each species of forb was studied and closely estimated. Its rank, whether high, intermediate or low, was ascertained only after examining a large part of each prairie. Size, abundance, duration, density of stand, and gregariousness were all considered. The general criterion for each species was the actual effect of the forb on the cover of grass and the proportion of the basal and foliage cover that it composed. Actually, the basal cover produced by forbs in true prairie averaged only $4.1 \%$ on upland and $3.6 \%$ on lowland. The foliage cover varied greatly; that of a single plant of a large coarse forb such as a rosin weed (Silphium laciniatum) sometimes occupied several square feet, but a hundred plants of flax (Linum sulcatum) only a few square inches. Because of their great differences in habits of growth, etc., forbs are considered separately from the grasses. An ecological description of each of the prairie forbs of high rank and most of those of intermediate rank has been given (Weaver and Fitzpatrick 1934).

The list of species forming societies of the first class in the prairies just described follows.

Amorpha canescens Lead plant
Antennaria neglecta Prairie cat's-foot

Aster cricoides Many-flowered aster

Baptisia leucophaea Large-bracted wild indigo

Ceanothus ovatus Redroot

Erigeron strigosus Daisy fleabane

Helianthus laetiflorus Stiff sunflower

Lespedeza capitata Round-headed bush clover Petalostemum candidum White prairie clover Petalostemum purpureum Purple prairie clover Psoralea tenuiflora Scurf pea

Schrankia nuttallii Sensitive briar 
In addition to 10 forbs the list also includes 2 shrubby species, Amorpha canescens and Ceanothus ovatus. Under annual mowing these behave as perennial forbs. Lead plant is perhaps the most conspicuous, most widely distributed, and most abundant of prairie plants except for certain grasses. Sensitive briar, although rarely occurring north of the Kansas-Nebraska border, is also a legume of considerable importance. All parts of this decumbent, widely spreading plant are thickly armed with hooked prickles.

The number of forbs of first rank in these prairies was very similar to that in many others. Over this grassland it usually varied between 7 and 15. Moreover, each of these species, except Baptisia leucophaea, was also of high rank in many other areas.

Species in the following list were of intermediate rank. Most were sufficiently abundant to form societies, others were merely scattered throughout.

Achillea millefolium Milfoil

1stcr azureus Sky-blue aster

Aster drummondi Drummond aster

J) sinodium canadense Showy tick trefoil

De'smodium illinoense Illinois tick trefoil

Echinacea pallida Pale purple coneflower

Euphorbia corollata Flowering spurge

Fragaria virginiana Scarlet strawberry

Kuhnia eupatorioides False boneset

Lialris scariosa Large button snakeroot

I.inum sulcatum Grooved flax

Rosa suffulta Prairie rose

K'udbeckia hirta Black-eyed Susan

Ruellia humilis Fringe-leaf ruellia

Silphium integrifolium Entire-leaved rosinweed

Silphium laciniatum Compassplant

Solidago graminifolia Bushy, fragrant goldenrod Solidago missouriensis Missouri goldenrod Viola pedatifida Prairie violet

Most of the preceding species formed societies of the first class in various other prairies, and also in individual prairies of this group. Only a few, Linum sulcatum, Ruellia humilis and Aster drummondi were consistently of lower rank. Conversely, a few species which were of highest rank in upland prairies elsewhere were found only among the species of low rank here. These are Astragalus crassicarpus, Coreopsis palmata, Liatris punctata, Psoralea argophylla, and Solidago rigida.

Species of low rank that were listed are given to complete the record; each is an integral part of the prairie. The list includes all species which were observed in the various prairies described.
Acerates angustifolia

Acerates hirtella

Acerates viridiflora

Allium canadense

Allium mutabile

Anemone cylindrica

Apocynum cannabinum

Artemisia ludoviciana

Asclepias sullivantii

Asclepias tuberosa

Asclepias verticillata

Asclepiodora viridis

Aster oblongifolius

Aster sericeus

Aster praealtus

Astragalus carolinianus

Astragalus crassicarpus

Baptisia leucantha

Boltonia asteroides

Cacalia tuberosa

Callirhoe alcaeoides

Cassia fasciculata

Circuta maculata

Cirsium undulatum.

Commandra umbellata

Commelina virginica

Corcopsis palmata

Delphinium virescens

Desmanthus illinoensis

Echinacea pallida

Equisetum arvense

Equisetum laevigatum

Eryngium yuccifolium

Erythronium albidum

Galium aparina

Galium tinctorium

Gaıra biennis

Gaura parififlora

Gentiana puberula

Glycyrrhiza lepidota

Helianthus grosseserratus

Hclianthus maximiliani

Helianthus salicifolius

Hclianthus tubcrosus

Heliopsis helianthoides

Hieracium longipilum

Houstonia nigricans

Hypoxis hirsuta

Liatris punctata

Liatris pycnostachy'a

Liatris squarrosa
Lilium philadelphicum

Lithospermum canescens

Lithospermum caroliniense

Lithospermum incisum

Lobclia inflata

Lobclia spicata

Lomatium orientale

Lycopus americanus

Lygodesmia juncea

Lythrum alatum

Monarda fistulosa

Oenothera biennis

Oenothera serrulata

Oenothera speciosa

Onosmodium occidentale

Oxalis stricta

Oralis violacea

Oxybaphus nyctagineus

Parosacla enneandra

Phlox pilosa

Physalis heterophylla

Physalis longifolia

Physalis virginiana

Polygala verticillata

Potentilla arguta

Psoralea argophylla

Psoralca esculenta

Ratibida columnifera

Ratibida pinnata

Rhus radicans

Salitia pitcheri

Scutcllaria leonardi

Silene anterrhina

Sisyrinchium angustifolium

Solidago altissima

Solidago canadensis

Solidago rigida

Solidago speciosa

Specularia perfoliata

Spiranthes cernua

Steironema ciliatum

Strophostyles helvola

Teucrium canadense

Thalictrum dasycarpum

Tradescantia bracteata

Verbena hastata

$V$ ernonia baldzini

Vernonia fasciculata

Vicia americana

Viola papilionacea

Zizia aurea

The number of forbs in prairie is very large. Although their abundance is highly variable they compose perhaps $5-15 \%$ of the vegetation. They are nearly always most abundant in prairies with good precipitation and, as will be shown, less abundant in drier ones. Competition for light between grasses and forbs is often great and readily observed. There is also much competition in the soil for water and nutrients. The roots of accompanying forbs have not been shown in figures 2 and 3 , but three general patterns of root systems of the perennial forbs are found among the grasses. 
A dozen or more species, such as pale purple coneflower and silver-leaf psoralea (Psoralea argophylla), have taproots or several main roots which produce relatively few or no branches, but which penetrate deeply and often far below the roots of the grass. Another group, including false boneset, prairie clovers, ground plum (Astragalus crassicarpus) and blazing star (Liatris punctata), has taproots with widely spreading branches which also pentrate deeply. Plants in this group probably absorb mostly from depths greater than those most thickly occupied by the roots of grasses. The type of forb that competes most severely with the roots of grasses includes plants such as manyflowered aster, stiff sunflower, Missouri goldenrod, and Baldwin's iron weed (Vernonia baldwrini). They spread by means of rhizomes and root offshoots or develop corms with numerous main roots of about equal size. Roots of species in this large group often compete severely with those of grasses, but also extend quite beyond the main depth ( $c f$. Weaver 1958a).

The beauty of the grassland is greatly enhanced by the presence and abundance of this great variety of forbs. Furthermore they add to its value for grazing and hay. On some hillsides the purple prairie clover grows so thickly that when in bloom its rose-purple color overshadows the green of the grasses. Redroot, where abundant, may greatly suppress the grasses; its profusion of white flowers lightens the prairie. Societies of black-eyed Susan, goldenrods and sunflower produce patches of yellow and gold. So numerous are the species and so variable are their groupings that each prairie seems different from the others.

\section{Kansas-Nebraska Loess Plains}

The western area is a part of the nearly level to gently rolling plain where the bedrock has been covered to a considerable depth by loess and loess-like materials. This area consists primarily of broad smooth divides with rolling land adjacent to narrow valleys draining into the Republican and Solomon Rivers in Kansas and the Republican and Blue Rivers in Nebraska. Some shallow and broken or stony lands occur adjacent to drainage ways. The bedrock consists primarily of heavy shales and limestone, but only a small percentage of the soils, chiefly on the steeper slopes, are developed directly on the bedrock (cf. Fly 1946). The area is characterized by the dominance of heavy clay or claypan-like soils on the smooth divides and by bedrock nearly completely covered by loess.

Silty clay loam soils prevail. They are Crete, Hastings and Nuckolls. The heavier Crete soils tend to occur on nearly level land. The first two soils are very dark grayish-brown. They developed from Peorian loess and occur on nearly level to rolling relief. Nuckolls soil is dark brown or reddish-brown. It has developed in an older, reddish-brown (Loveland) loess, which outcrops on the slopes. Minimum depth to bedrock is usually 4-5 ft and greater depths vary from 12-25 $\mathrm{ft}$ or more. The soils are relatively fertile and have good water-holding capacity but the subsoils vary in permeability from moderate in Nuckolls, to moderately slow in Hastings, to very slow in Crete. This large area lies in the eastern portion of the Chernozem soil zone and the layer of lime accumulation is usually at a depth of $5-6 \mathrm{ft}$. Wheat and corn are the principal crops, but corn has failed to produce profitable yields in years of low rainfall.

\section{Carleton Prairie}

Three miles southeast of Carleton there is a nearly level upland prairie of about 40 acres. A broad, shallow ravine extends diagonally across it. The soil is Crete silt loam. The topsoil is dark brown to black and coarsely granular. Lime accumulations are generally present at depths of 2-3 ft. A poorly developed claypan occurs throughout.

Vegetation was of the mixed-bluestem type. Little bluestem furnished $50-85 \%$, big bluestem $50 \%$ on low ground but often $20 \%$ elsewhere. The percentages at the western stations were obtained by repeated estimations and by data from numerous square-meter quadrats. Little bluestem showed a tendency to form small, distinct bunches rather than the usual sod-mat type and its stand was rather open. Even where big bluestem was best developed the sod was open, and Indian grass, switchgrass and Canada wild-rye occurred in small amounts; little bluestem was also usually intermixed. There were a few small areas of blue grama (Bouteloua gracilis) and buffalo grass (Buchloe dactyloides). Western wheatgrass was nearly confined to the swale where locally it formed a fourth to a third of the cover. Here a definite claypan was present at depths of about 10 to 28 in. This limited its root penetration to 3.5-4 ft. Over the area roots of bluestem grasses reached depths of 4-5 $\mathrm{ft}$.

Junegrass was a constant component of the vegetation, in amounts of $3-6 \%$, as were also Scribner's panic grass, Wilcox' panic grass, and side-oats grama in small amounts. Kentucky bluegrass was absent over much of the area but occurred locally in amounts of $5-15 \%$; tall dropseed (Sporobolus asper) and six-weeks fescue (Fes- 
tuca octoflora) occurred sparingly, and needlegrass only rarely.

The cover of vegetation was not only more open than usual but also the midsummer height of foliage was 6-8 in. less than in the preceding prairies. Nearly all tall, coarse forbs were absent and societies were fewer and poorer developed. There were only about 35 species of perennial forbs.

\section{Hebron Prairies}

Several areas of prairie were studied near Hebron, Nebraska. They occurred on rolling upland topography. The soil is Nuckolls silt loam into which water infiltrates readily, and one of good water-holding capacity. It is a deep Chernozem; carbonate accumulations occur at about 4-4.5 ft.

The prairie consisted largely of little bluestem, usually of the bunch grass type intermingled with $5-20 \%$ of big bluestem on the uplands, but on the drier slopes with a high percentage of side-oats grama and blue grama. Buffalo grass was rare but Junegrass and many species of forbs were abundant. Kentucky bluegrass occurred in small amounts more or less throughout the understory. Switchgrass and Indian grass occurred sparingly, mostly with big bluestem where it was dominant in ravines. Needlegrass was present in only small amounts. Western wheatgrass (Agropyron smithii) and tall dropseed grew on a few eroded banks of knolls.

The vegetation was better developed, species of forbs were greater in number, and societies were more plentiful than at Carleton. The openness of the cover, the presence of the short grasses, and the abundance of side-oats grama all indicated an approach to the Mixed Prairie of the Great Plains.

\section{Belleville Prairies}

Four miles east of Belleville, Kansas, there is a 30-acre prairie that is typical of several others nearby, which were also examined. The topography is rolling to hilly and native grassland covers long east, west, and north slopes. A welldeveloped broad ravine is also present.

The pervious black loam soil is derived from soft limestone materials. The lime rock occasionally lies within $3-4 \mathrm{ft}$ of the surface. At about $12 \mathrm{in}$. the topsoil gives way first to light brown, and then to yellow, clayey subsoil, which is less permeable. It is a deep soil with good water-holding capacity; both soil and subsoil are neutral in reaction.

This prairie was first studied in 1931. The low- est part of the ravine bore a pure stand of prairie cordgrass and several species of tall, coarse forbs. Bordering the cordgrass were excellent stands of big bluestem with a little Indian grass, and with switchgrass and Canada wild-rye on the wetter margins. There was a good understory of Kentucky bluegrass. A small patch of western wheatgrass grew in only one place. The higher land on all slopes was dominated by little bluestem with about $15 \%$ Junegrass and a considerable amount of big bluestem. No needlegrass was found. The steep portions of the hills showed almost pure alternes of buffalo grass and blue grama. Throughout these, as well as throughout the bluestem sod, side-oats grama was well distributed.

Height of little bluestem varied from 12 in. where it occurred in bunches on upper slopes to 18 in. in the sod-mat type on lower ground. Even in the best stands on lowland, the tall grasses were usually 1 to $3 \mathrm{ft}$ shorter than those in eastern Kansas and Nebraska. Forbs were of considerable abundance but societies were few and less well developed than eastward.

Prairies examined near Concordia and westward to Montrose were similar to the preceding.

\section{Montrose Prairie}

The Montrose prairie, three miles south of Montrose, Kansas, consisted of about 60 acres of moderately rolling land with some nearly level areas and shallow ravines. The soil, except in the ravines, is Hastings silty clay loam. The 6 in. layer of topsoil is a dark, pervious mantle of silt loam underlain by a subsoil consisting of about 20 in. of grayish to light brown, slightly compacted, silty clay loam above unweathered loess. Roots of grasses and forbs penetrated deeply.

Little bluestem composed 65 to $80 \%$ of the cover on upper slopes and hilltops; big bluestem and Indian grass were intermixed 5-20\% in the little bluestem type. Little bluestem occurred in both the sod-mat and bunch form. On the lower protected slopes and bottoms of ravines big bluestem, intermixed with Indian grass, had nearly complete possession. Higher, level ground was shared more or less equally by tall grasses and little bluestem. Side-oats grama composed 10-15\% of the cover in places, and with Junegrass was common, especially on dry slopes. Scattered spears of western wheatgrass, tufts of buffalo grass and blue grama were persent but nowhere abundant. Small amounts of Kentucky bluegrass and six-weeks fescue were found. Switchgrass occurred sparingly in the wetter draws. Some bunches of tall dropseed and more often those of sand dropseed (Sporobolus cryptandrus) were 
present. No needlegrass was seen, and prairie dropseed, as in the preceding western prairies, was absent.

A few of the 44 species of forbs formed well developed societies but few tall, coarse plants were present.

\section{Prairies near Nelson}

Several areas of prairie about 5 miles northeast of Nelson, Nebraska, were repeatedly examined before the great drought of 1933. Topography varied from level to rolling. The soil was mostly Crete silt loam. Vegetation was of the mixed bluestem type. The more arid climate was indicated by the great amount of little bluestem and by its poorer development, by increasing amounts of side-oats grama and short grasses, and by the occurrence of several species of grasses and forbs from the Great Plains.

On many of the level or slightly sloping uplands, little bluestem, either in the bunch or sodmat form, composed $80 \%$ or more of the cover. In midsummer it was only 10-12 in. high. In other places there was a mixture of $5-15 \%$, and sometimes more, of big bluestem. Elsewhere, as on lower slopes, the amount of big bluestem increased to $40 \%$ or more. But on low ground where one would expect to find good and nearly pure stands of this tall grass, half or nearly half of the cover was composed of mid grasses. Even locally where big bluestem occurred alone, the stands were not dense, and in midsummer the grass was only about $15-18$ in. tall.

Stands of little bluestem in drier places were often interrupted by alternes of blue grama, buffalo grass, and bunches of tall dropseed. Some dry knolls were occupied in part by western wheatgrass, sand dropseed and Junegrass. Side-oats grama was scattered throughout and was often $5 \%$ or more in local abundance. In some places six-weeks fescue, tumblegrass (Schedonnardus paniculatus) and bromegrass (Bromus tectorum) were intermixed with the other grasses. Lowgrowing panic grasses and penn sedge occurred in their usual 1-5\% abundance. Switchgrass and Canada wild-rye grew only in ravines and were never abundant. Indian grass rarely exceeded $1-3 \%$ in amount even on lowland. Bluegrass was found, usually under big bluestem, but it was nowhere abundant. Throughout the several prairies, totaling many acres, a rather low and continuous, but sometimes thick, cover of grass prevailed. Forbs were relatively few and societies only moderately well developed.

Prairies near Superior, Nebraska and across the state line southward in Kansas were so sim- ilar to those at Nelson and Montrose that separate description seems unnecessary. It should be pointed out, however, that some were even more xeric than any of the preceding.

\section{Summary of Grasses}

Little bluestem was the most abundant species. It usually composed 60 to $85 \%$ of the grasses. Its tendency to occur in bunches was pronounced and the bunches were often less filled with stems than similar ones eastward. Big bluestem dominated the lower land but its stands were less dense than eastward and sometimes contained much mid grass. Switchgrass, Indian grass, and Canada wild-rye were almost confined to lowland and did not occur in great abundance. Needlegrass and western wheatgrass were found rarely. Kentucky bluegrass was not abundant, sometimes absent, and grew mostly under big bluestem. Junegrass and Scribner's panic grass were far more abundant than eastward. Patches of blue grama and buffalo grass, often rather extensive, grew on the driest sites. Here tall dropseed, sand dropseed and six-weeks fescue were also found. Tumblegrass, purple three-awn and plains muhly (Muhlenbergia cuspidata) were sometimes present. Side-oats grama was widely spread and sometimes, intermixed with little bluestem, composed $10-15 \%$ of the cover. The total cover of grasses was less dense, foliage of mature mid grasses was 6-8 in. shorter and that of tall grasses $1-3 \mathrm{ft}$ shorter than eastward. Yield was considerably reduced.

\section{Prairie Forbs}

Species of forbs were much less abundant in the Loess Plains area. Only 6 species formed abundant and widely spread societies of the first class (Fig. 4). These were as follows:

Amorpha canescens Lead plant Antennaria neglecta Prairie cat's-foot Aster ericoides Many-flowered aster

Erigeron strigosus Daisy fleabane Schrankia nuttallii Sensitive briar Solidago mollis Velvety goldenrod

Velvety goldenrod is a xeric western species which was not listed in the preceding prairies. The others occurred abundantly eastward and, except for sensitive briar, ranged widely.

Species in the following list were of intermediate rank.

Artemisia ludoviciana Sage

Callirhoe alceoides Poppy mallow

Kuhnia eupatorioides False boneset

Liatris punctata Blazing star 


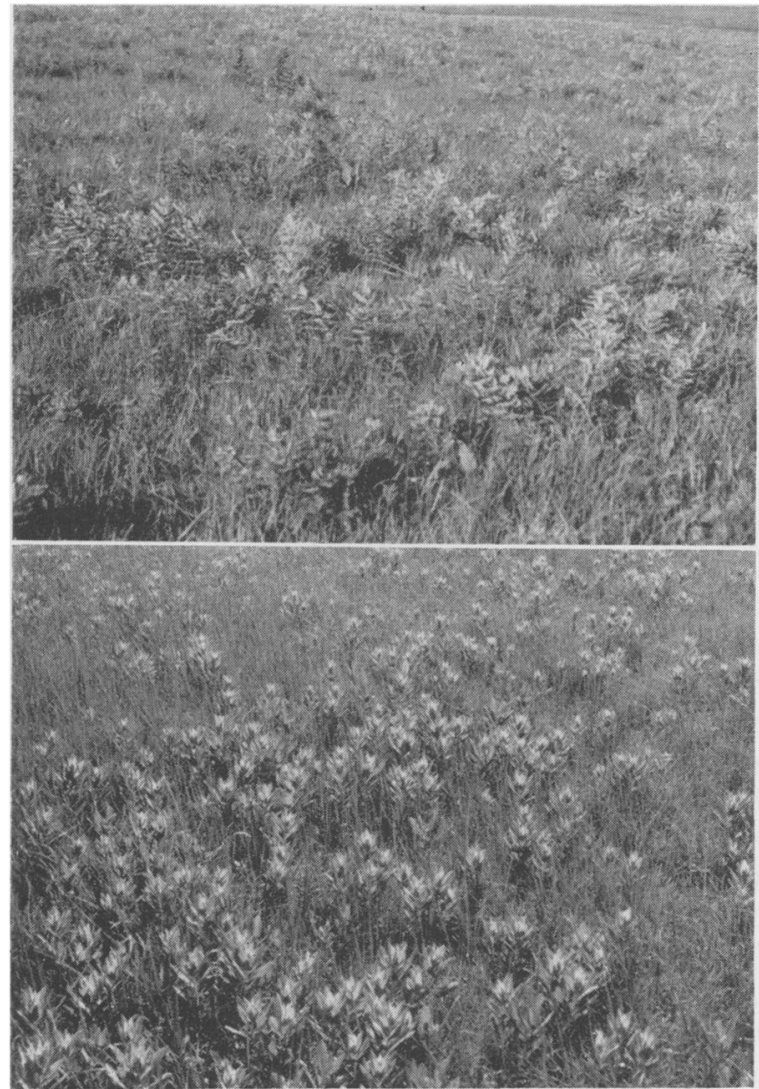

Fig. 4. Characteristic societies of forbs on the Loess Plains. (upper) Amorpha canescens and (lower) velvety goldenrod (Solidago mollis) in midsummer.

Linum sulcatum Grooved flax

Psoralea argophylla Silver-leaf psoralea

Senecio plattensis Prairie ragwort

Solidago missouriensis Missouri goldenrod

Three species occurred in the same rank and 4 were of lower rank, eastward. One, prairie ragwort, was not listed.

All the species that follow were of low rank. Those with an asterisk were not observed in the Drift-Loess Hills.

Abronia fragrans*
Acerates angustifolia
Acerates viridiflora
Achillea millefolium
Allium drummondi*
Allium mutabile
Anemone caroliniana*
Apocynum cannabinum
Asclepias pumila*
Asclepias sullivantii
Asclepias verticillata
Astragalus crassicarpus
Callirhoe involucrata*
Chrysopsis villosa*
Cirsium undulatum
Comandra pallida*
Dalea enneandra*

Lygodesmia juncea Microseris cuspidata* Oenothera biennis Oenothera serrulata Onosmodium occidentale Opuntia macrorhiza* Oxalis stricta

Oralis violacea Oxybaphus linearis* Orytropis lambertii* Penstemon cobaea Penstemon grandiflorus* Petalostemum candidum Petalostemum purpureum Physalis lanceolata Plantago purshii* Polygala verticillata
Delphinium virescens Euphorbia dentata

Galium aparine

Gaura coccinea*

Gentiana puberula

Glycyrrhiza lepidota

Haplopappus spinulosus*

Hedeoma hispida*

Helianthus laetiflorus

Helianthus maximiliani

Hieracium longipilum

Hymenopappus tenuifolius*

Lespedeza capitata

Liatris punctata

Liatris scariosa

Liatris squarrosa

Lithospermum canescens

Lithospermum incisum

Lomatium foeniculaceum

Lomatium orientale

Lotus americanus*

This list of 76 species is fairly long; added to the species of higher rank it totals 90 , as compared with a total of 131 eastward. This results in part from the presence of 21 species common to Mixed Prairie which were not found eastward. The number of species alone, however, does not give an accurate picture of the much less abundant forb population. Tall-growing species were few, societies were not abundant, and they were much less well developed in this drier western area.

\section{Discussion}

Differences between the vegetation west of the Flint Hills and east of them was recognized by an early botanist (Schaffner 1926). He had been intimately acquainted with the prairies of Kansas since 1871. He states that "in passing from Clay County [see Fig. 1] to Douglas County [adjoining Jefferson County on the south] a distance of 100 miles, one experienced a remarkable change in the character of the species on all the ordinary and higher levels, while the transition from Douglas County, Kansas, to Franklin County, Ohio, a distance of about 600 miles, is much less marked."

The greater aridity of the western prairie was shown in many ways. In prairies of the DriftLoess Hills that had been heavily pastured for several years, the bluestems were replaced by Kentucky bluegrass and with varying amounts of shrubs, such as smooth sumac, coralberry, and roughleaf dogwood. But on the Loess Plains the bluestems usually gave way under grazing to short grasses, blue grama and buffalo grass. Even the shallow ravines became clothed with buffalo grass, although bluegrass sometimes grew in the more moist, deeper ones.

As a result of the severe and prolonged drought 
of 1933-40 Mixed Prairie grasses and forbs moved eastward 100-150 mi. and actually replaced the bluestems and most accompanying species in mowed True Prairie of the Loess Plains. But eastward from the $32 \mathrm{in.}$ isohyet, while the prairie suffered some damage, it was relatively slight in comparison and recovery was complete (Weaver 1943).

The change from True Prairie to Mixed Prairie westward does not result in the complete replacement of the bluestems. They still occur in sandy soil or other favorable sites, but their dominance is usually replaced by that of western mid and short grasses. Those shown in Figure 5 are representative. All are deeply rooted and are highly drought evading or drought resistant. The short grasses are short only above ground. Their root to top ratio is much greater than that of the mid grasses. A similar trend occurs between roots and tops of dry-land forbs. The appearance of these grasses in the western edge of True Prairie and their increase in abundance is clearly indicative of a less mesic environment than in the excellent bluestem prairies of the I)rift-Loess Hills.

\section{SumMary}

The Drift-Loess Hills of northeastern Kansas and southeastern Nebraska are not unlike the Loess Plains in topography, except that the hills are more pronounced in the east and more level land alternates with lower hills in the Loess Plains westward. Both have highly productive soils. Eastward glacial boulders and limestone outcrops are common. On the Loess Plains the bedrock is nearly completely covered with loess. Soils in the Chernozem Zone westward are somewhat less productive than those in the Brunizem Zone eastward, not because of lack of innate fertility, but because of reduced precipitation. Precipitation ranges from 29-34 in. in the east to $27-28$ in. in the west. Since altitude and latitude are similar, the length of the growing season is nearly the same. Humidity is lower and drying winds are higher and more frequent in the west. Evaporation is also greatly increased westward and periods of drought are more frequent and of longer duration.

Both areas of True Prairie are composed of the Andropogon scoparius type on uplands and the $A$. gerardi type on lower slopes and low, level lands. On mid slopes the two bluestems may intermix about equally. In the west, the little bluestem type occupies a greater portion of the prairie than eastward, the grass more often occurs as bunches and frequently intermixes with big bluestem on lower slopes. Sporobolus heterolepis is common and sometimes locally abundant eastward; it did

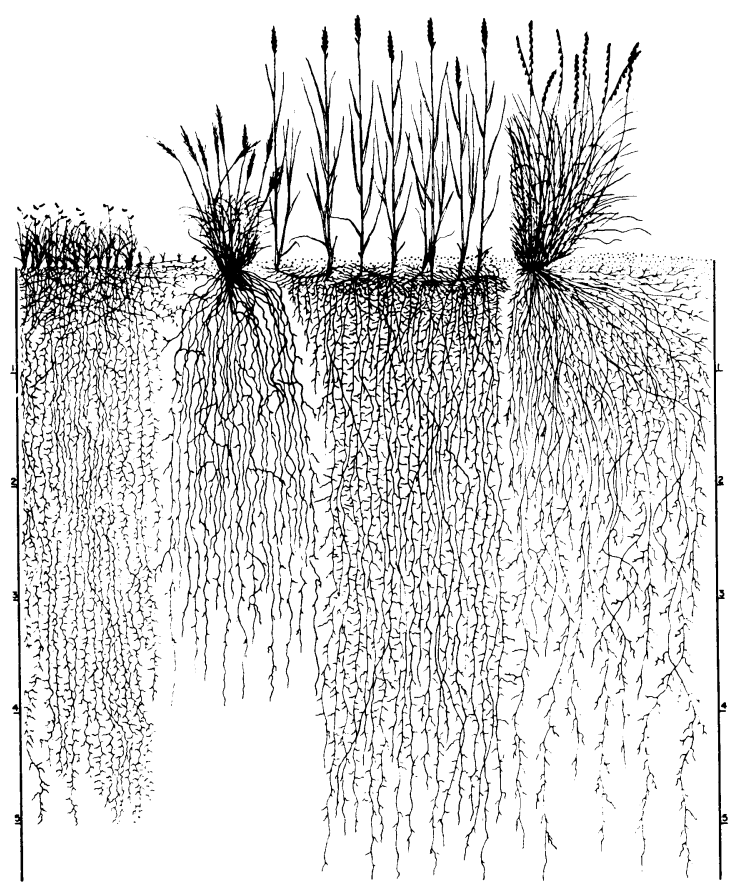

FIG. 5. Tops and roots of dominant grasses common to mixed prairie. Only those parts in a strip 1 in. wide are shown. From left to right are buffalo grass (Buchloe dactyloides), (height and depth of which is very similar to that of blue grama), purple three-awn (Aristida purpurea), western wheatgrass (Agropyron smithii) and side-oats grama (Bouteloua curtipendula).

not occur at the western stations. Stipa spartea was common but rarely abundant eastward; it was usually absent in the west. Panicum virgatum and Sorghastrum nutans were of considerable abundance (5-20\%) eastward and ranged widely; westward they were much less abundant and more restricted to ravines and low ground.

Midsummer foliage level of little bluestem was often 16-24 in. in the east but 8-18 in. westward; similar average heights of big bluestem were 1826 and 26-36 in. The general foliage cover was not only higher but also considerably denser eastward. Westward, Bouteloua curtipendula and Koeleria cristata became far more abundant, and the low-growing Panicum scribnerianum, $P$. wilcoxianum and Carex pennsylvanica greatly increased in amount. Great Plains grasses, not observed in mowed prairies eastward but common westward, were Bouteloua gracilis and Buchloe dactyloides. The following species of Mixed Prairie grasses also occurred in some western mowed prairies: Agropyron smithii, Aristida purpurea, Festuca octoflora, Schedonnardus paniculatus and Muhlenbergia cuspidata.

In the bluestem prairies of northeastern Kansas and southeastern Nebraska 65 to 100 species of 
forbs were usually observed in selected prairies 40-60 acres in extent. Westward the lists were shorter, 35 to 60 species. Forbs were greatly reduced in stature westward, there were fewer and less well developed societies, and numerous species common to Mixed Prairie were present.

\section{REFERENCES}

Bidwell, O. W. 1956. Major soils of Kansas. Kans. Agr. Expt. Sta. Circ. 336.

Fly, C. L. 1946. Natural agricultural resource areas of Kansas. Rept. Kans. State Board Agric. pp. 126195.

Frye, J. C. and A. B. Leonard. 1951. Stratigraphy of the Pleistocene loesses of Kansas. Jour. Geol. 59: 287.

Hanna, R. M. and O. W. Bidwell. 1955. The relation of certain loessial soils of northeastern Kansas to the texture of the underlying loess. Soil Sci. Soc. Amer. Proc. 19: 354-359.

Leonard, A. B. and J. C. Frye. 1954. Ecological conditions accompanying loess deposition in the Great Plains region of the United States. Jour. Geol. 62: 399.

Schaffner, J. H. 1926. Observations on the grasslands of central United States. Ohio State Univ. Studies, Contr. Vol. 178: 1-56.
Thornber, J. J. 1901. The prairie-grass formation in region I. Rep. Bot. Surv. Univ. Nebr. 5: 29-143.

Thornthwaite, C. W. 1931. The climates of North America according to a new classification. Geographical Review 21: 633-655.

Weaver, J. E. 1943. Replacement of True Prairie by Mixed Prairie in eastern Nebraska and Kansas. Ecology 24: 421-434.

__ 1954. North American prairie. Johnsen Pub. Co. Lincoln, Nebr.

- 1958. Summary and interpretation of underground development in natural grassland communities. Ecological Monog. 28: 55-78.

- 1958a. Classification of root ssytems of forbs of grassland and a consideration of their significance. Ecology 39: 393-401.

- 1958b. Native grassland of southwestern Iowa. Ecology 39: 733-750.

- 1960. Flood plain vegetation of the central Missouri Valley and contacts of woodland with prairie. Ecological Monog. In press.

- and T. J. Fitzpatrick. 1932. Ecology and relative importance of the dominants of tall-grass prairie. Bot. Gaz. 93: 113-150.

and 1934. The prairie. Ecological Monog. 4: 109-295. 